\title{
Pengaruh Penambahan Minyak Kelapa dan Sawit Terhadap Sifat Fisik dan Tribologi Pelumas SAE 40
}

\author{
Dedison Gasni ${ }^{1}{ }^{\star}$, KM Abdul Razak ${ }^{1)}$, Ahmad Ridwan ${ }^{1)}$, Muhammad Arif ${ }^{1)}$ \\ 1) Jurusan Teknik Mesin, Fakultas Teknik Universitas Andalas \\ Kampus Limau Manis, Padang 25163 \\ Email: d.gasni@ft.unand.ac.id,kmabdulrozak@gmail.com, ridwankun.ahmad@gmail.com, \\ sambarang14@gmail.com
}

doi: https://doi.org/10.24843/METTEK.2019.v05.i01.p01

\begin{abstract}
Abstrak
Penelitian ini bertujuan untuk mengetahui efek dari penambahan minyak kelapa dan sawit terhadap sifat fisik dan tribologi pelumas SAE 40. Vegetabel oil, seperti; minyak kelapa dan sawit, memiliki nilai viskositas indek yang tinggi dan sifat pelumasan yang baik terutama didaerah boundary lubrication jika dibandingkan dengan mineral oil (SAE 40). Hal ini disebabkan karena vegetabel oil memiliki kandungan fatty acids yang tidak dimiliki oleh mineral oil. Keunggulan lain dari minyak kelapa dan sawit adanya sifat yang ramah lingkungan karena mudah terurai di alam dan dapat diperbaharui. Pada penelitian ini sifat yang baik dari minyak kelapa dan sawit ini akan dimanfaatkan sebagai zat aditif pada minyak pelumas SAE 40. Pengujian dilakukan terhadap sifat fisik dan tribology dengan penambahan $5 \%, 10 \%, 15 \%$, dan $20 \%$ berat dari minyak kelapa dan sawit ke dalam minyak pelumas SAE 40. Pengujian sifat fisik terdiri dari pengukuran viskositas pada temperatur $40^{\circ} \mathrm{C}$ dan $100^{\circ} \mathrm{C}$ dan viskositas index. Pengujian sifat tribologi untuk menentukan keausan dan koefisien gesek berdasarkan ASTM G99 dengan menggunakan alat uji pin on disk. Dari hasil pengujian diperoleh bahwa dengan penambahan minyak kelapa dan sawit kedalam minyak pelumas SAE 40 terjadi peningkatan viskositas indeks. Peningkatan viskositas indeks sebanyak $17 \%$ dengan penambahan $20 \%$ minyak sawit. Terjadi perubahan sifat tribologi dengan penambahan minyak sawit, berupa penurunan keausan dan nilai koefisien gesek dibandingkan dengan penambahan minyak kelapa.
\end{abstract}

Kata kunci: Minyak Kelapa, Minyak sawit, keausan, koefisien gesek

\begin{abstract}
This study aims to determine the effect of coconut and palm oils as additives to physical and tribological properties of SAE 40 lubricating oil. Vegetable oils, such as; coconut oil and palm oil, have high viscosity index and good lubrication properties, especially in boundary lubrication compared to mineral oil. This is due to vegetable oil having fatty acids that are not owned by mineral oil. The advantages of coconut oil and palm oil are environmentally friendly properties because they are biodegradable and renewable. In this study, the good properties of coconut and palm oils will be used as additives in SAE 40 lubricating oil. Tests are carried out on the physical and tribological properties with the addition of $5 \%, 10 \%, 15 \%$, and $20 \%$ by weight of coconut and palm oils into SAE 40 lubricating oil. Physical properties testing consists of measuring viscosity at temperatures of $40^{\circ} \mathrm{C}$ and $100^{\circ} \mathrm{C}$ and viscosity index. The tribological test is to determine wear and coefficient of friction based on ASTM G99 using a pin on disc test equipment. From the test results, it was found that coconut and palm oils as additives into SAE 40 lubricating oil could increase in viscosity index. The increase of the viscosity index was $17 \%$ by adding $20 \%$ of palm oil. There was a change of tribological properties in the form of decreasing on the wear and the coefficient of friction with the addition of palm oil compare to addition of coconut oil.
\end{abstract}

Keywords: Coconut oil, palm oil, wear, coefficient of friction 


\section{PENDAHULUAN}

Pelumas selain berfungsi sebagai lapisan yang memisahkan dua komponen mesin yang mengalami kontak langsung, seperti pada bantalan dan roda gigi, untuk mengurangi gesekan dan keausan, juga berfungsi sebagai media untuk mendinginkan mesin, membawa debris atau kotoran, dan mencegah korosi dari dua permukaan yang berkontak. Pada saat ini ada beberapa jenis pelumas yang beredar di pasaran, seperti mineral oil, minyak sintetik, dan biolubricant. Sekitar $80 \%$ dari minyak pelumas yang beredar di pasaran, merupakan mineral oil yang didapat dari hasil penyulingan minyak bumi, $8 \%$ berasal dari minyak sintetis, dan hanya sebagian kecil dari minyak pelumas tersebut yang berasal dari minyak nabati. Minyak pelumas terdiri dari 80-90 \% base oil dan 10-20\% merupakan zat aditif [1]. Hal ini mengakibatkan pemakaian minyak mineral oil dan sintetis semakin meningkat, sehingga pencemaran terhadap lingkungan akan terus berlanjut sehubungan dengan sifat dari mineral oil dan minyak sintetis bersifat racun pada lingkungan. Disamping itu, sifat pelumas yang berasal dari mineral oil tidak dapat diperbaharui, sehingga sumber dari mineral oil ini akan habis [2,3]. Untuk itu perlu dilakukan usaha untuk mengurangkan pemakaian dari pelumas berbahan mineral oil sebagai minyak dasar dan zat aditif untuk pembuatan pelumas. Sebagai bahan pengganti dari pemakaian mineral oil ini dapat menggunakan vegetable oil. Pemanfaatan vegetable oil ini sebagai bahan pelumas lebih menguntungkan diantaranya ramah lingkungan, dapat diperbaharui, memiliki viskositas indek yang tinggi, dan sifat pelumasan yang baik terutama di daerah boundary lubrication [4] dan mudah larut dengan zat aditif[6].

Sumatera Barat memiliki sumber vegetable oil yang melimpah seperti: minyak kelapa dan minyak sawit yang ditanam oleh perkebunan rakyat maupun perkebunan industri. Pada saat ini pemanfaatan vegetabel oil tersebut masih terbatas untuk kosmetik, obat-obatan, dan makanan. Sebenarnya, pemanfaatan vegetabel oil sebagai bahan pelumas telah lama digunakan oleh masyarakat dalam kehidupan sehari-hari, tetapi bukti secara ekperimental mengenai sifat pelumasan atau tribologi belum banyak dilakukan. Dalam pembuatan minyak pelumas, vegetable oil dapat digunakan sebagai base oil dan sebagai zat aditif. Pemakaian vegetable oil sebagai zat aditif telah dilakukan oleh M. A. Kalam dkk [6] dengan menggunakan minyak Jatropha sebagai zat aditif dan minyak mineral oil (SAE 40) sebagai base oil. Presentase dari komposisi penambahan minyak Jatropha akan mengakibatkan terjadinya perubahan sifat fisik dan tribologi dari pelumas tersebut. Hal ini disebabkan oleh adanya kandungan fatty acid yang terdapat dalam vegetable oil yang memiliki viskositas yang tinggi $[7,4]$.

Pada penelitian ini minyak kelapa dan minyak sawit akan dimanfaatkan sebagai zat aditif untuk minyak mineral oil SAE 40. Prosentase dari penambahan minyak kelapa pada minyak mineral oil SAE 40 divariasikan dan diamati bagaimana pengaruhnya terhadap sifat fisik dan sifat tribologinya. Pengujian sifat fisik terdiri dari: pengujian viskositas pada temperatur $40{ }^{\circ} \mathrm{C}$ dan $100{ }^{\circ} \mathrm{C}$ dan viskositas index. Sifat tribologi terdiri dari uji keausan, pengukuran scar diameter, dan koefisien gesek.

\section{METODE}

\subsection{Persiapan Sampel dari Minyak Kelapa, Minyak Sawit, dan Oli SAE 40}

Sampel dari minyak kelapa dan minyak sawit diperoleh dari toko P dan D. Sedangkan pelumas SAE 40 diperoleh dari pelumas yang dijual secara komersil di pasaran. Tabel 1 memperlihatkan perbandingan sifat fisik antara minyak kelapa, minyak sawit dan pelumas SAE 40.

Tabel 1.Perbandingan sifat fisik dari minyak kelapa, minyak sawit [8] dan pelumas SAE 40 [9]

\begin{tabular}{llccc} 
No & Sifat Fisik dan Kimia & Minyak Kelapa & Minyak Sawit & $\begin{array}{c}\text { Pelumas } \\
\text { SAE 40 }\end{array}$ \\
\hline 1 & Viskositas @ $40{ }^{\circ} \mathrm{C}(\mathrm{cSt})$ & 26,58 & 40,01 & 133,4 \\
& Viskositas @ $100{ }^{\circ} \mathrm{C}(\mathrm{cSt})$ & 5,76 & 8,931 & 13,66 \\
2 & Viskositas Index & 178 & 213 & 98 \\
3 & Flash Point $\left({ }^{\circ} \mathrm{C}\right)$ & 303,5 & 305,5 & 242 \\
4 & Pour Point $\left({ }^{\circ} \mathrm{C}\right)$ & 21 & 6 & -9 \\
5 & Densitas $\left(\mathrm{Kg} / \mathrm{m}^{3}\right)$ & 925,6 & 915,4 & 895 \\
\hline
\end{tabular}

Gasni, dkk./METTEK Vol 5 No 1 (2019) 1 - 9 


\subsection{Pencampuran Minyak Kelapa dan Minyak Sawit Dengan Oli SAE 40}

Pencampuran minyak kelapa dan minyak sawit dengan pelumas SAE 40 ini dilakukan dengan penambahan persentase masing-masing 5\%, 10\%, 15\%, dan $20 \%$ dari berat minyak kelapa dan minyak sawit ke dalam pelumas SAE 40 dengan berat masing-masing $95 \%, 90 \%$, $85 \%$, dan $80 \%$. Kedua minyak dicampur ke dalam gelas ukur kemudian diaduk selama 10 menit.

\subsection{Analisis Sifat Fisik}

Analisis sifat fisik dari minyak pelumas terdiri dari viskositas dan viskositas indeks. Viskositas dari sampel minyak pelumas ditentukan pada temperatur $40{ }^{0} \mathrm{C}$ dan $100{ }^{0} \mathrm{C}$. Viskositas pada temperatur $40{ }^{\circ} \mathrm{C}$ dan $100{ }^{\circ} \mathrm{C}$ dilakukan berdasarkan ASTM D445-14 menggunakan Capillary Viscometer 200-629A dan Capillary Viscometer 100-S2X. The viscosity index (VI) dihitung berdasarkan ASTM D2270-04.

\subsection{Pengujian keausan dan Koefisien Gesek}

Pengujian keausan dan koefisien gesek dilakukan dengan menggunakan alat uji pin on disk berdasarkan standar ASTM G99. Alat uji pin on disk ini dapat digunakan untuk menentukan wear volume dari pin dan disk akibat terjadinya gerak relatif antara pin dan disk. Scar diameter yang terbentuk diukur melalui hasil foto tektur permukaan dengan menggunakan mikroskop optik. Koefisien gesek dapat ditentukan dengan mengukur gaya gesek dengan menggunakan load cell yang dipasang pada lengan flexibel. Material dari disk terbuat dari besi alloy dengan komposisi kimia dapat dilihat pada Tabel2. Diameter dari dis $\mathrm{k}$ sebesar $100 \mathrm{~mm}$ dengan kekerasan sebesar 449.5 BHN dan kekasaran permukaan dari disk adalah sekitar 1,04 $\mu \mathrm{m}$ Ra.

Tabel 2.Komposisi kimia dari material disk

\begin{tabular}{llllll}
\hline Komposisi & Fe (\%) & C (\%) & Si (\%) & Mn (\%) & Cr (\%) \\
\hline$\%$ & 98,18 & 0,129 & 0,323 & 0,959 & 0,195 \\
\hline
\end{tabular}

Komposisi kimia dari material pin dapat dilihat pada Tabel3 dengan kekerasan permukaan dari pin sebesar 660,5 BHN dan diameter dari pin sebesar $5 \mathrm{~mm}$. Komposisi kimia da ri material pin dapat dilihat pada Tabel 3 .

Tabel 3.Komposisi kimia dari material pin

\begin{tabular}{lllll}
\hline Komposisi & Fe (\%) & C (\%) & Si (\%) & Cr (\%) \\
\hline$\%$ & 95,05 & 3,07 & 0,24 & 1.63 \\
\hline
\end{tabular}

\section{HASIL DAN PEMBAHASAN}

Pengujian telah dilakukan pada 8 sampel dari minyak pelumas dengan variasi persentase minyak kelapa dan minyak sawit masing-masing sebesar 5\%,10\%,15\% dan 20\%. Selanjutnya, 8 sample minyak pelumas tersebut dilakukan pengujian, yang terdiri dari pengujian sifat fisik, viskositas dan viskositas index, dan pengujian sifat tribologi, yang terdiri dari wear, pengukuran scar diameter dan koefisien gesek dinamik yang terjadi antara pin dan disk.

\subsection{Pengaruh Persentase Penambahan Minyak Kelapa dan Minyak Sawit pada SAE 40 terhadap Viskositas dan Viskositas Indeks}

Hasil dari pengujian viskositas kinematik pada temperatur $40^{\circ} \mathrm{C}$ dan $100^{\circ} \mathrm{C}$ dari penambahan minyak kelapa dan minyak sawit pada pelumas SAE 40 dengan variasi masing-masing sebanyak 5\%, 10\%, 15\%, dan 20\%dapatdilihat pada Gambar 1 dan 2. Dari gambar tersebut 
dapat dilihat bahwa nilai viskositas kinematik baik pada temperatur $40^{\circ} \mathrm{C}$ dan $100^{\circ} \mathrm{C}$ cenderung turun dengan variasi penambahan minyak kelapa dan minyak sawit. Penurunan nilai viskositas kinematik terbesar terjadi pada penambahan minyak kelapa. Penurunan viskositas kinematik pada temperatur $100^{\circ} \mathrm{C}$ untuk penambahan $20 \%$ minyak sawit dan kelapa sekitar 27-35\% dibandingkan dengan viskositas kinematik dari pelumas SAE 40. Gambar 3 memperlihatkan nilai Viskositas Indeks yang dihitung berdasarkan ASTM D2270-04. Pada Gambar 3 tersebut memperlihatkan grafik variasi dari penambahan minyak kelapa dan minyak sawit dengan pelumas SAE 40 terhadap viskositas index. Dari Gambar 3 dapat dilihat bahwa dengan penambahan minyak kelapa dan minyak sawit dengan variasi masing-masing sebanyak 5\%,10\%, 15\%, dan 20\%akan menyebabkan peningkatan viskositas index. Ratarata terjadi peningkatan nilai viskositas indek dari minyak campuran dengan meningkatnya prosentase penambahan minyak kelapa dan minyak sawit. Penambahan $20 \%$ minyak kelapa dan minyak sawit terjadi peningkatan nilai viskositas indeks, masing-masing meningkat sebesar $13 \%$ dan $17 \%$.

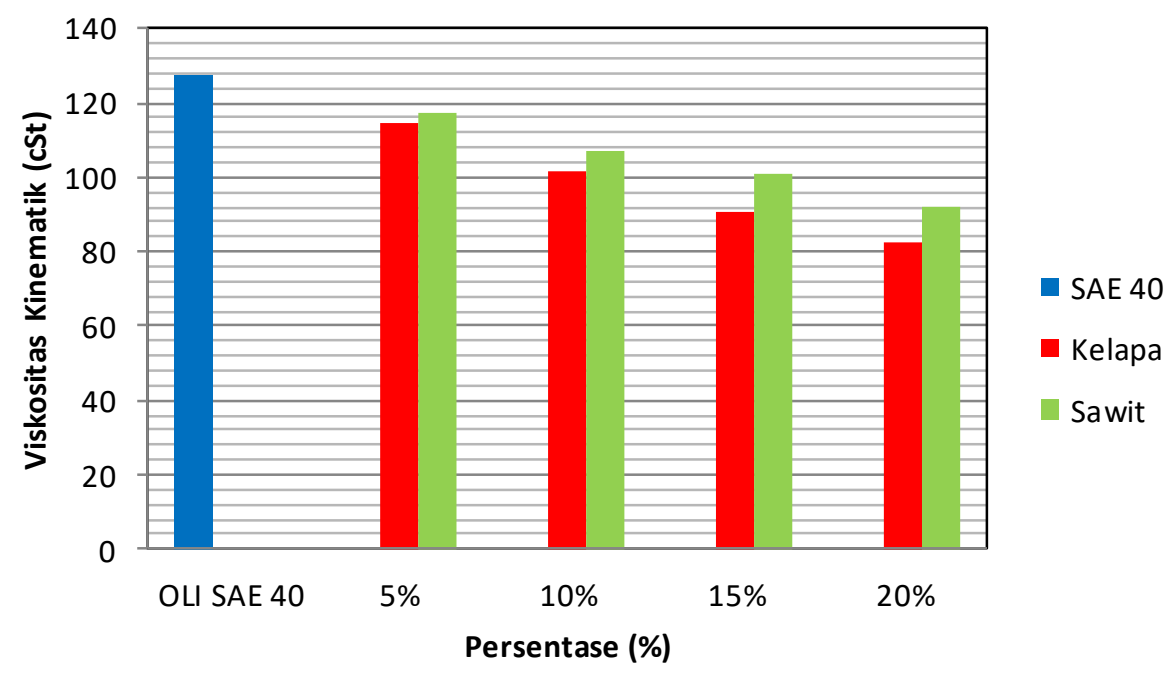

Gambar 1.Grafik perbandingan variasi persentase penambahan minyak kelapa dan minyak sawit pada pelumas SAE 40 terhadap viskositas pada temperatur $40^{\circ} \mathrm{C}$.

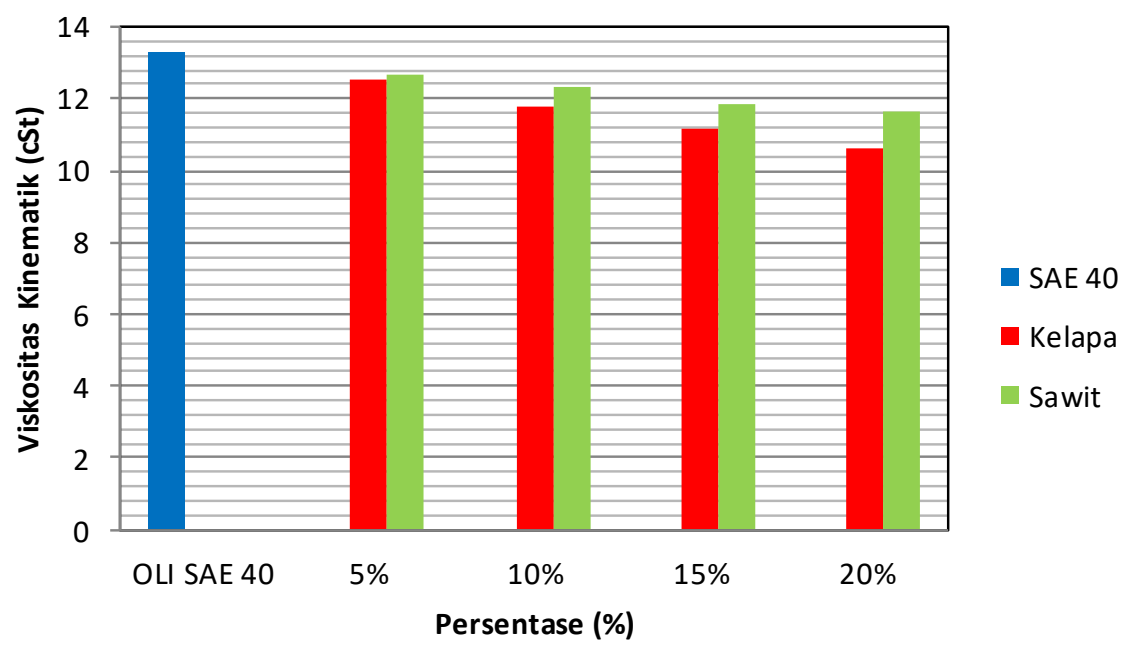

Gambar 2.Grafik perbandingan variasi persentase penambahan minyak kelapa dan minyak sawit pada pelumas SAE 40 terhadap viskositas pada temperatur $100^{\circ} \mathrm{C}$. 


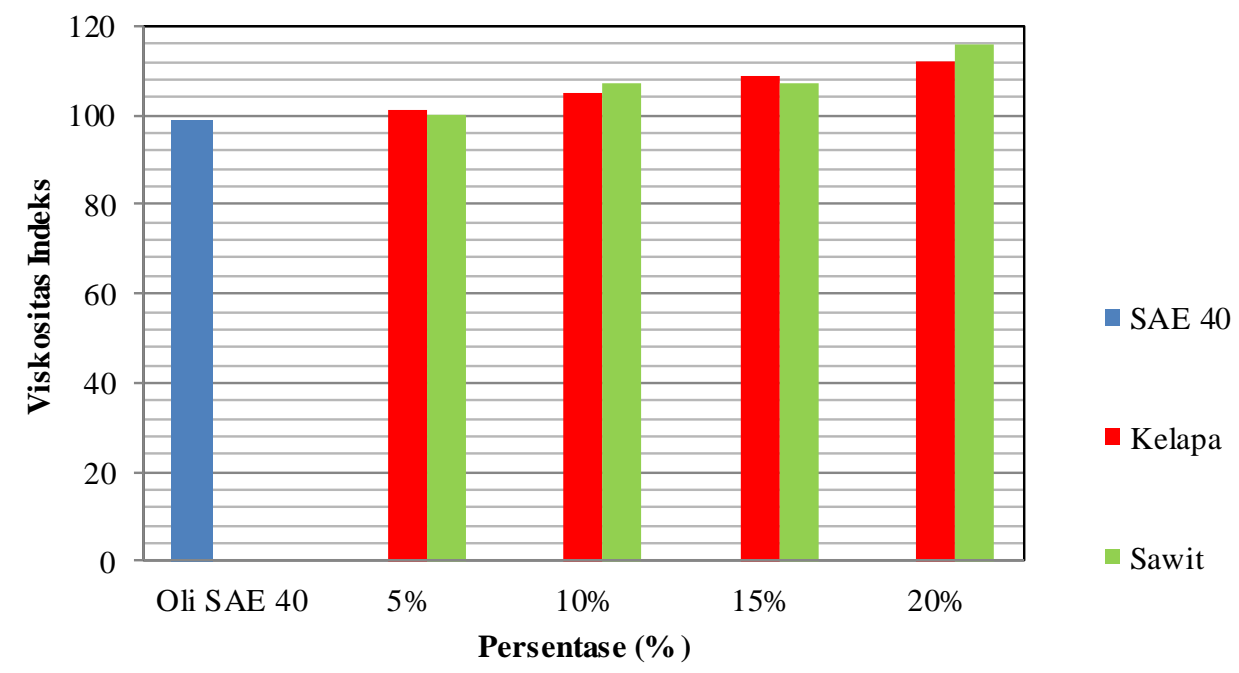

Gambar 3.Grafik perbandingan variasi persentase penambahan minyak kelapa dan minyak sawit pada pelumas SAE 40 terhadap viskositas index.

\subsection{Pengaruh Persentase Penambahan Minyak Kelapa dan Minyak Sawit pada pelumas SAE40 terhadap Keausan Pin dan Disk}

Hasil pengujian keausan (wear) dengan menggunakan alat uji keausan pin on disk dapat dilihat pada Gambar 4. PadaGambar4 memperlihatkan keausan abrasif yang terjadi pada pin dan disk dengan variasi penambahan presentase minyak kelapa dan minyak sawit masingmasing 5\%, 10\%, $15 \%$ dan 20\%. Keausan dari pin dan disk dengan semua variasi penambahan minyak sawit cendrung turun dengan meningkatnya variasi persentase dari minyak sawit, dengan penambahan $15 \%$ dan $20 \%$ minyak sawit keausan yang terjadi pada pin dan disk lebih kecil jika dibandingkan dengan keausan pada pelumas SAE 40. Sebaliknya, pada variasi penambahan minyak kelapa pola keausan yang terjadi pada pin dan disk tidak seperti penambahan minyak kelapa sawit. Penambahan minyak kelapa dengan persentase $15 \%$ dan $10 \%$ memperlihatkan keausan pin dan disk yang lebih rendah dari pelumas SAE 40.

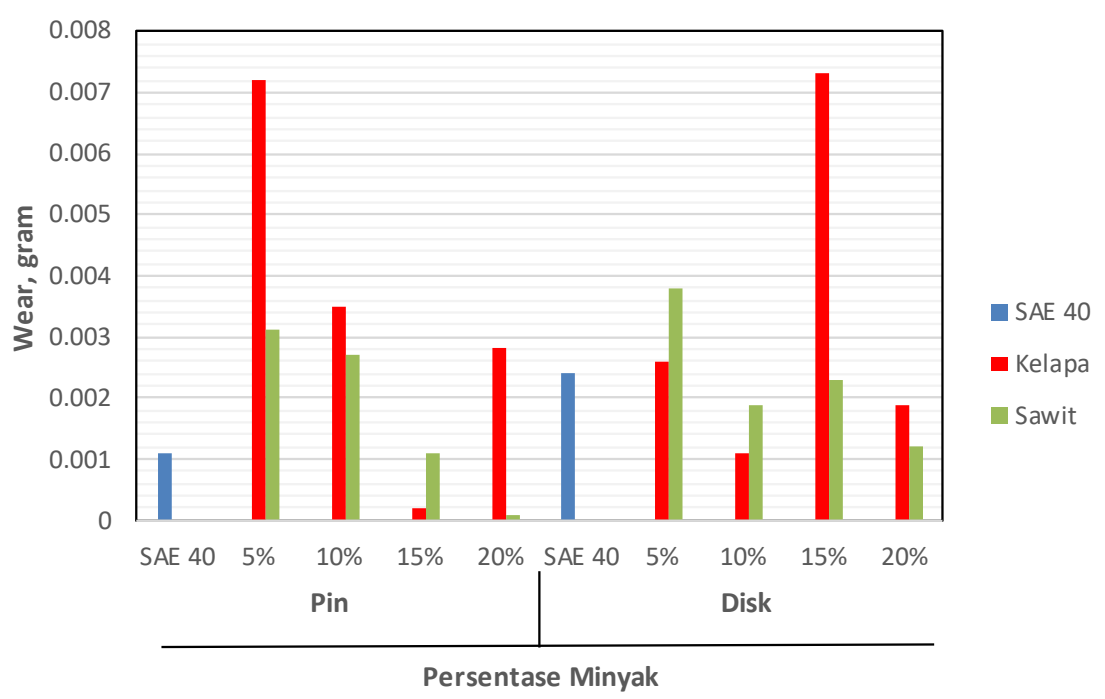

Gambar 4.Grafik perbandingan wear dari pin dengan variasi penambahan minyak kelapa dan minyak sawit dengan beban $30 \mathrm{~N}$ dengan kecepatan putaran disk $1200 \mathrm{rpm}$ selama 30 menit 


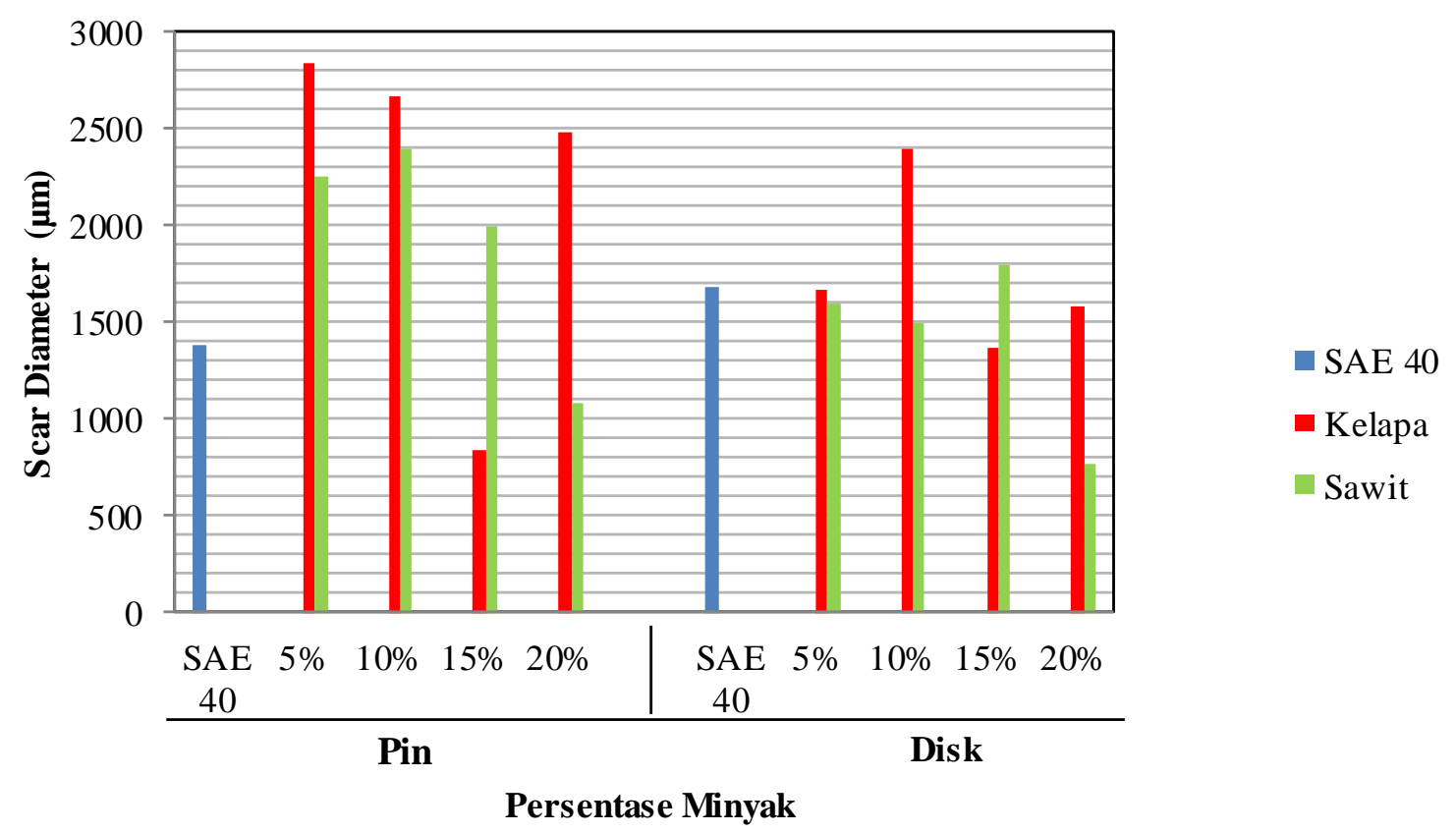

Gambar 5.Grafik perbandingan scar diameter dari pin dengan variasi penambahan minyak kelapa dan minyak sawit dengan beban $30 \mathrm{~N}$ dengan kecepatan putaran disk $1200 \mathrm{rpm}$ selama 30 menit

Pada Gambar 5 memperlihatkan scar diameter dari pin dengan variasi penambahan presentase minyak kelapa dan minyak sawit masing-masing 5\%, 10\%, 15\% dan 20\%. Secara umum dari Gambar 4dapat dilihat bahwa scar diameter dari pin dan disk dengan semua variasi penambahan minyak kelapa dan minyak sawit lebih tinggi jika dibandingkan dengan scar diameter pada pelumas SAE 40. dengan penambahan semua variasi minyak sawit. Penambahan minyak sawit dengan persentase $20 \%$ memperlihatkan scar diameter pin dan disk yang lebih rendah dari pelumas SAE 40. Sedangkan scar diameter yang terendah terjadi pada pin dan disk pada pencampuran pelumas dengan penambahan minyak kelapa sebesar $15 \%$.

\subsection{Pengaruh Persentase Penambahan Minyak Kelapa dan Minyak Sawit pada SAE 40 terhadap Koefisien Gesek}

Data koefisien gesek didapat dengan melakukan pengujian dengan menggunakan alat ujipin on disk, dengan beban sebesar $30 \mathrm{~N}$ dan putaran $1200 \mathrm{rpm}$. Hasil data yang diperoleh dari pengujian koefesien gesek untuk penambahan variasi minyak sawit dan minyak kelapa dapat dilihat pada Gambar 6 dan 7. Pada Gambar 5 terlihat bahwa koefisien gesek dari pelumas SAE 40 lebih tinggi dari koefesien gesek dengan penambahan minyak sawit. Variasi dari penambahan minyak sawit pada pelumas SAE 40 tidak berbeda secara signifikan untuk nilai koefesien geseknya. Pada penambahan minyak kelapa pada pelumas SAE 40 sebesar $5 \%$ dan $10 \%$ koefisien gesek lebih rendah dari koefesien gesek pelumas SAE 40. Sedangkan penambahan minyak kelapa $20 \%$ menghasilkan nilai koefesien gesek yang terbesar. 


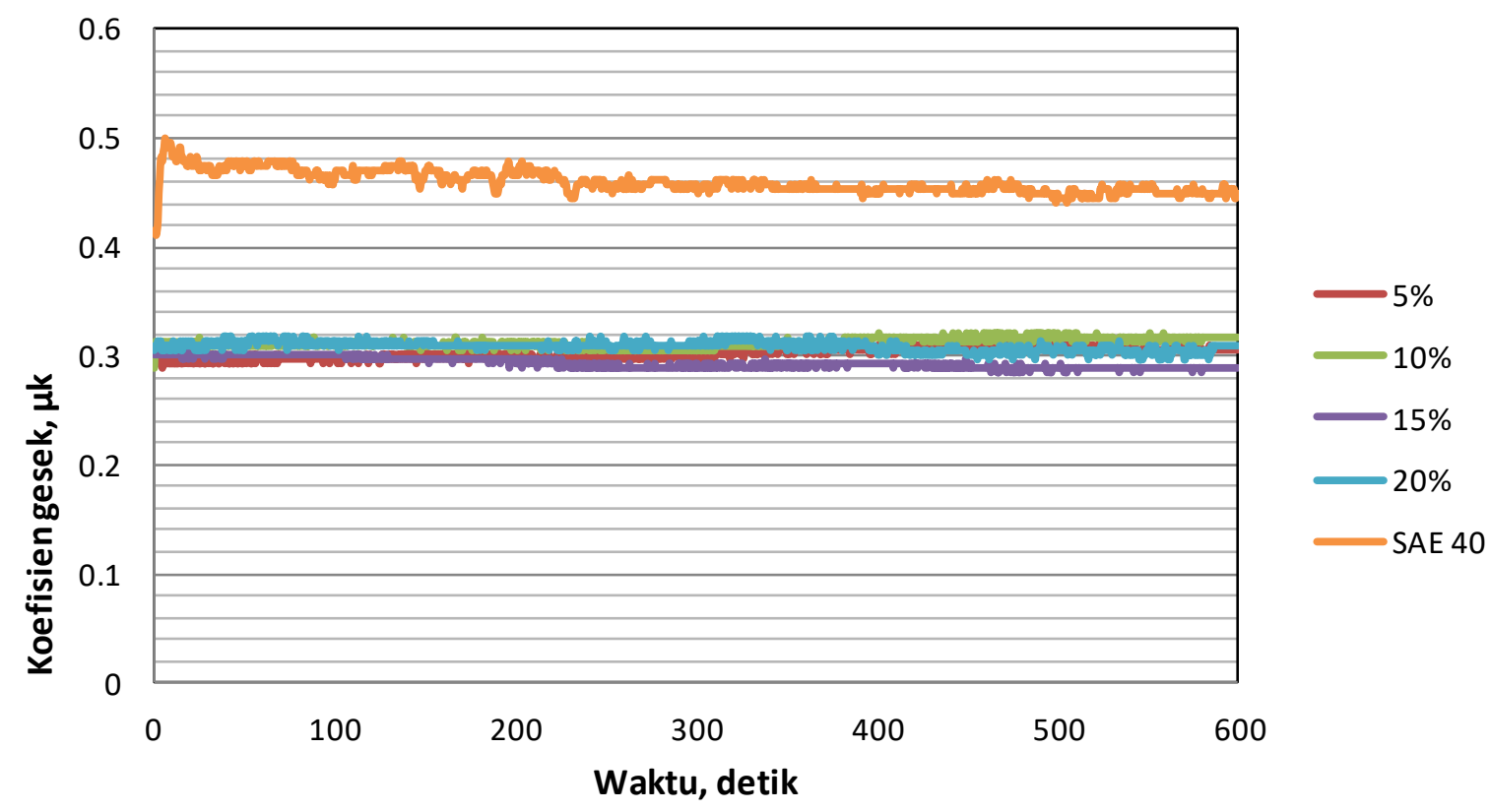

Gambar 6.Grafik perbandingan koefisien gesek dengan penambahan minyak sawit sebesar $5 \%, 10 \%, 15 \%, 20 \%$ dengan beban $30 \mathrm{~N}$ dan putaran $1200 \mathrm{rpm}$.

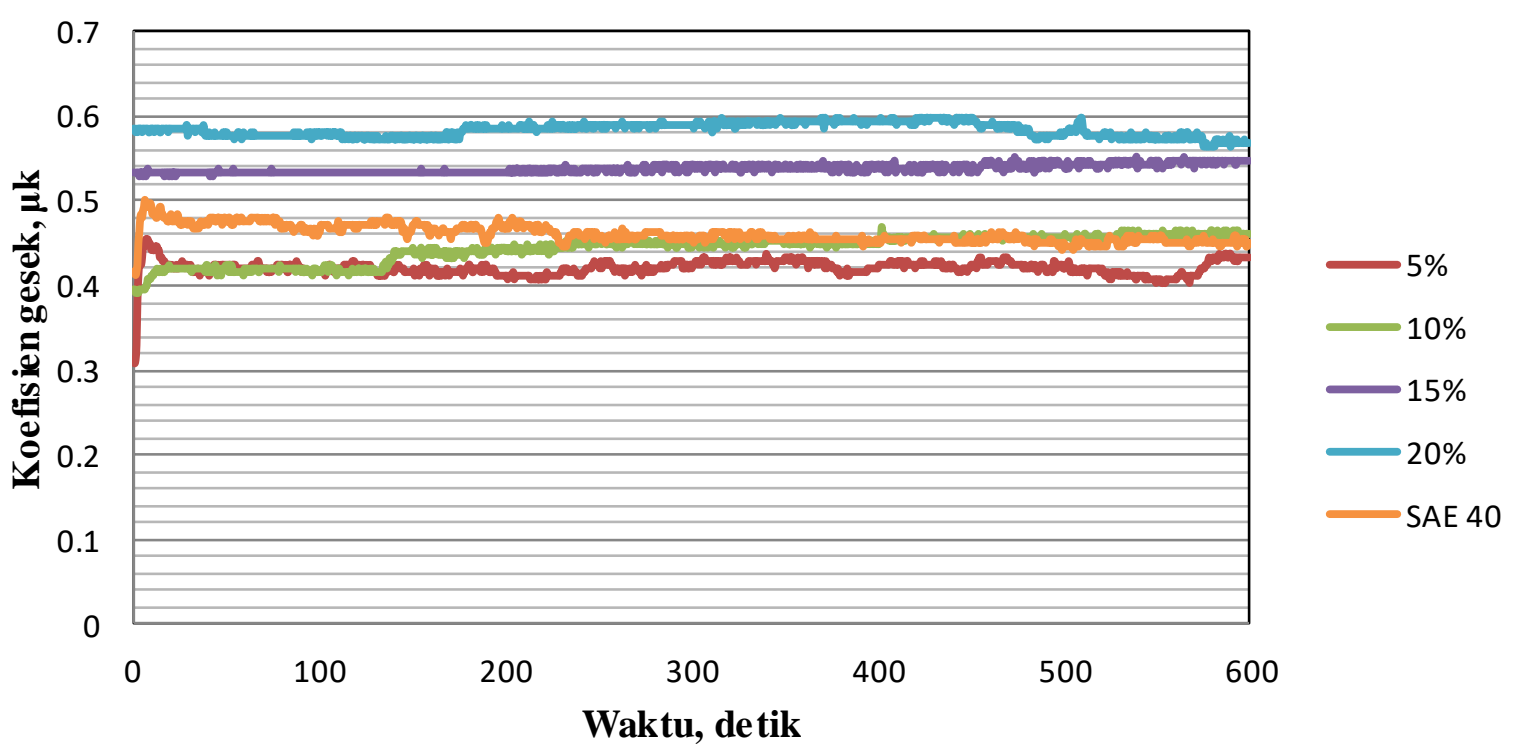

Gambar 7.Grafik perbandingan koefisien gesek dengan penambahan minyak kelapa sebesar $5 \%, 10 \%, 15 \%, 20 \%$ dengan beban $30 \mathrm{~N}$ dan putaran $1200 \mathrm{rpm}$.

Berdasarkan data hasil pengujian yang telah dijelaskan pada sub-bab di atas dan data lengkap yang telah didapatkan dimana terlihat adanya perubahan nilai viskositas kinematik dan viskositas index dari minyak hasil campuran antara penambahan minyak kelapa dengan persentase yang bervariasi dengan pelumas SAE 40. Nilai viskositas kinematik dari minyak hasil campuran dengan penambahan minyak kelapa dan minyak sawit dengan persentase yang bervariasi pada umumnya menurun. Hal ini disebabkan oleh viskositas kinematik dari minyak kelapa dan minyak sawit pada temperatur $40^{\circ} \mathrm{C}$ dan $100^{\circ} \mathrm{C}$ nilainya dibawah viskositas kinematik dari pelumas SAE 40 seperti terlihat pada Tabel 1. Hal ini disebabkan karena 
viskositas dari minyak kelapa dan minyak sawit lebih kecil dari viskositas dari pelumas SAE 40, sehingga viskositas dari hasil pencampuran juga akan kecil. Begitu juga dengan nilai viskositas kinematik dari minyak kelapa lebih rendah dari minyak sawit sehingga penurunan viskositas dari campuran minyak pelumas SAE 40 dengan minyak sawit lebih rendah dengan penambahan minyak kelapa.

Viskositas index dari minyak campuran antara minyak kelapa dan minyak sawit dengan persentase yang bervariasi dengan pelumas SAE 40 pada umumnya cendrung naik diatas harga viskosita index dari pelumas SAE 40 sebesar 98. Harga viskositas index minyak campuran yang tertinggi terjadi pada campuran minyak sawit $20 \%$. Penyebab tingginya nilai viskositas index ini adalah adanya kandungan fatty acid dalam minyak kelapa dan minyak sawit [7,10]. Dari penelitian yang dilakukan oleh Gasni et. al., 2017 komposisi kandungan fatty acids antara minyak kelapa dan minyak sawit tidak jauh berbeda dimana kedua minyak tersebut kaya akan kandungan lauric acid (C12.0) [11].

Pengujian keausan dengan menggunakan alat uji pin on disk menunjukkan bahwa keausan yang terjadi pada disk dan pin dengan menggunakan pelumas SAE 40 yang dicampur dengan minyak kelapa lebih tinggi dari pelumasan yang ditambah dengan minyak sawit. Hal ini disebabkan adanya pengaruh dari nilai viskositas kinematik dari minyak sawit yang lebih tinggi dari viskositas kinematik dari minyak kelapa, seperti ditunjukkan pada Tabel 1. Viskositas kinematik yang tinggi akan berpengaruh pada tebal lapisan film yang memisahkan antara pin dan disk, sehingga lapisan film yang tebal ini berfungsi untuk mencegah keausan yang terjadi pada pin dan disk. Viskositas sangat berpengaruh pada pelumas anter utama didaerah elastohydrodynamic lubrication karena nilai viskositas akan mempengaruhi tebal dan tipisnya lapisan yang memisahkan antara dua material yang berkontak. Jika tebal lapisan film yang memisahkan dua permukaan yang berkontak semakin tebal akan mencegah terjadinya kontak antara dua permukaan sehingga keausan dapat dihindari, tetapi jika tebal lapisan film sangat tipis akan mengakibatkan keausan pada bagian yang berkontak. Sewaktu terjadi sliding antar pin dengan permukaan disk akan menyebabkan terjadinya gesekan yang menyebabkan terjadinya peningkatan temperatur, temperatur yang tinggi akan mempengaruhi nilai viskositas kinematik dari pelumas, karena minyak pelumas yang ditambahkan minyak sawit memiliki viskositas indeks yang tinggi sehingga viskositas kinematiknya tidak banyak berubah sehingga keausan yang terjadi pada pin dan disk akan berkurang.

Hasil pengujian gesek, menunjukkan bahwa koefesien gesek dengan menggunakan pelumasan SAE 40 yang ditambah variasi minyak sawit dan minyak kelapa menunjukkan nilai koefesien gesek yang lebih rendah jika dibandingkan dengan koefesien gesek dari pelumas SAE 40.Hal ini disebabkan karena pengujian koefisien gesek dilakukan pada kondisi steady state, dimana kedalaman dari daerah deformasi plastis yang terjadi pada permukaan disk cenderung konstan sehingga laju keausan pada permukaan disk dan pin juga cenderung konstant [12]. Disamping pengaruh viskositas indeks, regime lubrication juga akan mempengaruhi nilai koefesien gesek[13].

\section{SIMPULAN}

Dari hasil penelitian yang telah dilakukan dapat ditarik beberapa kesimpulan:

1. Pengaruh penambahan minyak kelapa dan sawit dengan variasi 5\%,10\%, 15\%, dan $20 \%$ pada pelumas SAE 40 menyebabkan penurunan secara linear nilai viskositas kinematik pada temperatur $40^{\circ} \mathrm{C}$ dan $100^{\circ} \mathrm{C}$. Semakin tinggi persentase minyak kelapa dan sawit pada pelumas SAE 40 akan meningkatkan nilai viskositas indeks dari pelumas hasil campuran. Nilai viskositas indeks dari pencampuran pelumas SAE 40 
dengan minyak sawit lebih baik jika dibandingkan dengan penambahan minyak kelapa.

2. Keausan abrasif yang terjadi pada permukaan pin dan disk dengan menggunakan pelumas SAE 40 yang ditambahkan dengan minyak sawit lebih baik jika dibandingkan dengan penambahan minyak kelapa. Semakin tinggi variasi minyak sawit yang ditambahkan semakin kecil keausan yang terjadi.

3. Terjadi perubahan sifat tribologi berupa peningkatan nilai koefisien gesek pelumas SAE 40 ditambah minyak sawit dibandingkan dengan koefesien gesek pelumas SAE 40 saja.

\section{UCAPAN TERIMA KASIH}

Penulis mengucapkan terima kasih kepada Rektor Universitas Andalas melalui riset skema Jurusan Teknik Mesin melalui DIPA Tahun 2019.

\section{DAFTAR PUSTAKA}

[1] Kailas M. Talkit, D. T. Mahajan, V. H. Masand, Study on physicochemical properties of vegetable oils and their blends use as possible ecological lubricant, Journal of Chemical and Pharmaceutical Research 4(12), 5139-5144, 2012.

[2] J. Salimon, N. Salihand E. Yousif,Biolubricants: Raw materials, chemical modifications and envi-ronmental benefits, Eur. J. Lipid Sci. Tech.112, 519-530, 2010.

[3] Adhvaryu A, Liu Z, Erhan S.,Synthesis of novel alkoxylated triacylglycerols and their lubricant base oil properties, Industrial Crops and Products21, 113-119, 2005.

[4] Adhvaryu, A., Erhan, S.Z.,Epoxidized soybean oil as a potential source of hightemperature lubricants, Ind. Crop. Prod. 15 (3), 247-254, 2002.

[5] Bilal S., Mohammed-Dabo I. A., Nuhu M1, Kasim, S. A., Almustapha I. H. and Yamusa Y. A.,Production of biolubricant from jatropha curcas seed oil, J. Chem. Eng. Mater. Sci. 4 (6), 72-79, 2013.

[6] M. Shahabuddin, H. H. Masjuki, and M.A. Kalam, Experimental investigationinto tribological characteristics of bio-lubricant formulated from jatropha oil, Procedia Engineering 56, 597-606, 2013.

[7] M. Allawzi, M.K. Abu-Arabi, H.S. Al-zoubi and A.Tamimi,Physicochemical characteristics and thermal stability of jordanian jojoba oil, J. Am. Oil Chem. Soc.75 (1), 67-62, 1998.

[8] Gasni D, MulyadiHI, and Affi J,Comparison of Physical and Tribological Properties of Coconut Oils Extracted from Dry and Wet Processing, In: Proceeding of Malaysian Tribology Conference, 217-19, 2015.

[9] MTU Friedrichshafen, Fluids and lubricants specifications, Germany, 2012

[10] Quinchia LA, Delgado MA, Reddyhoff T, Gallegos C, Spikes HA,Tribological Studies of Potential vegetable oil-based lubricants containing environmentaly friendly viscosity modifiers, Tribol. Int. 69, 110-17, 2014.

[11] Gasni D., Mulyadi H.I., Affi J., and Miswar A.Y.,Investigation of wear mechanism in ball bearings lubricated by a bio-lubricant, Int. J. of Tech. 7, 1248-57, 2017.

[12] Suh, N.P. and Sridharan, P., Relationship between the coefficient of friction and the wear rate of metal, Wear 34, 291-299, 1975.

[13] Gasni, D and Rahmat, S., Menentukan regime pelumasan pada ball bearing dengan menggunakan kurva Stribeck. Jurnal METTEK 3 (1), 21-28, 2017. 